\title{
Effect of Buspirone on Fetuses of the Pregnant Rats
}

\author{
Nadia G. Zaki and Magdy H. Abouel-Magd
}

Narcotic Research Department, the National Center for Social and Criminological Research, Cairo, Egypt

\begin{abstract}
Aim of the work: the purpose of this study was to detect effect of buspirone hydrochloride (Buspar) on the structure of cerebellum cortex of the fetuses of the pregnant rats. Material and methods: buspirone hydrochloride tablets are an antianxiety. Buspirone hydrochloride (buspar) tablets were obtained from SmithKline Beecham-Haram-Giza- Egypt. Thirty pregnant female rats were randomly categorized into three groups (Ten pregnant female rats in each group). Group I (control group) pregnant rats were administered oral doses of distilled water, group II: in this group pregnant rats were treated with buspirone hydrochloride, they were administered oral doses of drug in the distilled water equivalent to $0.27 \mathrm{mg} / 100 \mathrm{~g}$. body weight/day respectively for 15 days from the $6^{\text {th }}$ day to the $20^{\text {th }}$ day of gestation. , group III: pregnant rats were treated with to oral doses of buspirone hydrochloride in the distilled water equivalent to 0.41 $\mathrm{mg} / 100 \mathrm{~g}$. body weight/day respectively for 15 days from the $6^{\text {th }}$ day to the $20^{\text {th }}$ day of gestation. Pregnat rats of all groups were sacrificed on the $20^{\text {th }}$ day of gestation and their fetuses were obtained for the histopathological and histochemical studies. Results: treatment of pregnant rats with buspirone hydrochloride (buspar) showed many dystrophic changes in brain of their fetuses; these changes were more obvious in case of the toxic dose of buspirone which resulted in some sorts of neurotoxic structural changes in the cerebellum of fetuses of pregnant rats as evident by deformity in the cerebellar layers and degeneration of Purkinje cells. Conclusions: buspirone hydrochloride (buspar) has many adverse effects on the fetal cerebellum tissue.
\end{abstract}

Keywords: fetal rats, buspirone drug, cerebellum cortex, histopathology and histochemistry.

\section{INTRODUCTION}

Anxiety is an emotion characterized by an unpleasant state of inner feelings, often accompanied by nervous behavior, such as pacing back and forth, somatic complaints and rumination (1). Anxiety can be appropriate, but when experienced regularly the individual may suffer from a disorder. Anxiety disorder refers to specific psychiatric disorders that involve extreme fear or worry, and includes generalized anxiety disorder , panic disorder and panic attacks, agoraphobia, social anxiety disorder, selective mutism, separation anxiety, and specific phobias ${ }^{(2)}$.

A number of psychoactive agents are currently availablefor the treatment of anxiety. As a class the benzodiazepineshave been most frequently used, although some are associated with sedative side effectsincluding impairment of psychomotor and cognitivefunction. Consequently, therapeutic efficacy needsto be balanced against unwanted behavioral effects ${ }^{(3)}$.

Buspirone, an anxiolytic drug with selective affinity for the 5-hydroxytryptamine receptor $\left(5-\mathrm{HT}_{1 \mathrm{~A}}\right)$ subtype of serotonin receptor, Buspirone hydrochloride 8-[4-(4-pyrimidin-2-ylpiperazin-1yl)butyl]-8-azaspiro[4.5]decane-7,9-dione;

hydrochloride, is an anti anxiety agent, a partial agonist of serotonin receptor $\left(5-\mathrm{HT}_{1 \mathrm{~A}}\right)$ and a mixed agonist/antagonist on dopamine receptors that is not chemically or pharmacologically related to the benzodiazepines, barbiturates or other sedative / anxiolytic drugs but it has an efficacy comparable to diazepam in treating generalized anxiety disorder $^{(1-3)}$. It is also effective against depression, obsessive compulsive disorder, attention deficit hyperactivity disorder. Buspirone hydrochloride (molecular formula $\mathrm{C}_{21} \mathrm{H}_{32} \mathrm{ClN}_{5} \mathrm{O}_{2}$, molecular weight $421.97 \mathrm{~g} / \mathrm{mol}^{-1}$ ) is supplied as tablets for oral administration containing 5,7.5, 10 or $15 \mathrm{mg}^{(4)}$. This work aimed to study the structure of cerebellar cortex tissue of fetuses of pregnant rats treated with buspirone hydrochloride.

\section{MATERIAL and METHODS \\ -Material \\ -Drug used}

Buspirone hydrochloride (buspar) was obtained as tablets from SmithKline BeechamHaram-Giza- Egypt. The drug was dissolved in distilled water and given orally by a gastric tube. The daily single oral dose was $0.27 \mathrm{mg}$ and 0.41 $\mathrm{mg} / 100 \mathrm{~g}$ body weight/day respectively. The dose for rats was calculated according to the method Paget and Barnes ${ }^{(5)}$ formula on the basis of the human dose.

\section{- Experimental animals}

The present study was carried out on thirty Sprague dawley pregnant adult rats with average weight $150-200 \mathrm{~g}$. They were taken from the 
Animal House of El-Nasr Pharmaceutical Chemicals Co. Rats were randomly categorized into three groups and fed on ordinary rat diet.

\section{Animal grouping:}

Adult Sprague dawley rats (Females and males) were mated in the proportion of two females for one male over night. Each morning a vaginal smear was taken to check for the presence of sperms or plug in the vagina. Zero day of pregnancy was considered to be the day on which sperms or plug were found in the vagina. They were randomly categorized into three groups (Ten pregnant female rats in each group).

-Group I (control group): pregnant rats were administered oral doses of distilled water only.

- Group II (Therapeutic dose group): pregnant rats were treated with buspirone hydrochloride, they were administered oral doses of the drug in the distilled water equivalent to 0.27 $\mathrm{mg} / 100 \mathrm{~g}$.body weight/day respectively for 15 days from the $6^{\text {th }}$ day to the $20^{\text {th }}$ day of gestation.

- Group III (toxic dose group): pregnant rats were treated with oral doses of buspirone hydrochloride in the distilled water equivalent to $0.41 \mathrm{mg} / 100 \mathrm{~g}$. body weight/day respectively for 15 days from the $6^{\text {th }}$ day to the $20^{\text {th }}$ day of gestation.

\section{- Methods \\ - Histopathological study}

All pregnant rats were sacrificed on the $20^{\text {th }}$ day of gestation after 4 hours from the last dose administration and their fetuses were picked out and fixed in formalin (10\%) and Bouin's solution for the histopathological and histochemical purposes. Sections were prepared for light microscopic examination. Slides were stained with hematoxylin and eosin stain according to the method reported by Bancroft and Gamble ${ }^{(6)}$.Total proteins were detected by using mercuric bromophenol blue method ${ }^{(7)}$. Polysaccharides were detected by using periodic acid Schiff's (PAS) reagent ${ }^{(8)}$. Amyloid protein was detected by Congo red technique ${ }^{(9)}$ and collagen fibres were stained by using Mallory's trichrome stain method ${ }^{(\mathbf{1 0})}$.

\section{RESULTS}

- Group I (control group) fetuses on the $20^{\text {th }}$ day of gestation showed that:

1) Hematoxylin and eosin: examination of stained sections of fetal cerebellum of the control group revealed the normal three layered structure of cerebellum; the outer molecular layer, ill distinct Purkinje cells layer, the inner granular cells layer and the core of white matter (Fig.1-3).
2) Mercuric bromophenol blue stain: examination of fetal cerebellum of the control group revealed the normal protein content in the Purkinje cells and granular layer cells with less contents in the molecular layer (Fig.4).

3) Periodic acid Schiff (PAS): in PAS stained sections of fetal rats, normal distribution of PAS +ve materials was detected in all the cortical layers with dense staining affinity in Purkinje cells and granular layer cells (Fig.5).

4) Congored stain: showed normal slight deposition of amyloid $\beta$ protein in the nuclei of Purkinje cells with negative Congo red reaction in the remaining layers of the fetal cerebellar cortex (Fig.6).

5) Mallory's trichrome stain: showed ill distinct thin bundles of collagen fibers (arrows) in the cerebellar cortical layers of fetal cerebellar cortex (Fig.7).

- Group II (Therapeutic dose group): fetuses of the pregnant rats which were treated with buspirone hydrochloride in a dose of 0.27 $\mathrm{mg} / 100 \mathrm{~g}$. body weight/day respectively for 15 days from the $6^{\text {th }}$ day to the $20^{\text {th }}$ day of gestation showed that:

1) Hematoxylin and eosin: examination of stained sections of the cerebellum of fetal rats treated maternally with low dose of buspirone hydrochloride revealed microvacuolation in the neuropia of the outer molecular layer and the granular layers, partial separation of the Purkinje cells layer from the inner granular cells layer of the cerebellar cortex, degenerative changes in the Purkinje cell layer in the form of partialloss of the Purkinje cells, shrinkage of some Purkinje cells, pericellular vacuolation around some Purkinje cells (Figs.8,9)

2) Mercuric bromophenol blue stain: examination of the cerebellum of fetuses treated maternally with the low dose of buspirone hydrochloride revealed mild reduction in protein content in the different layers of cerebellum (Fig.10).

3) Periodic acid Schiff (PAS): in PAS stained sections of the cerebellum of fetuses showed mild decrease in the PAS +ve materials especially in the shrinked Purkinje cells (Fig.11).

4) Congo red stain: showed mild increase in deposition of amyloid- $\beta$ protein in all layers of the fetal cerebellum (Fig.12).

5) Mallory's trichrome stain: showed increased deposition of collagen fibres especially in the granular layer of the fetal cerebellum (Fig.13).

- Group III (toxic dose group): fetal rats of mothers subjected to treatment with oral doses of 
buspirone hydrochloride in the distilled water equivalent to $0.41 \mathrm{mg} / 100 \mathrm{~g}$. body weight/day respectively for 15 days from the $6^{\text {th }}$ day to the $20^{\text {th }}$ day of gestation showed that:

1) Hematoxylin and eosin: examination of stained sections of the fetal cerebellum exposed maternally to the high dose of buspirone revealed marked vacuolation, macrovacuolation and separation in the neuropia of the outer molecular layer and the granular layers, marked separation of the Purkinje cells layer from the inner granular cells layer, marked degenerative changes in the disrupted Purkinje cells layer in the form of marked empty spaces due to loss of the most of Purkinje cells, marked shrinkage of the most darkly stained Purkinje cells and marked pericellular vacuolation around most of Purkinje cells (Figs.14,15).
2) Mercuric bromophenol blue stain: examination of fetuses of the high dose group showed marked reduction in protein content in the different layers of cerebellum (Fig.16).

3) Periodic acid Schiff (PAS): in PAS stained sections of fetuses of the high dose group showed marked decrease in the PAS +ve materials in the destructed Purkinje cells and the granular layer (Fig.17).

4) Congo red stain: showed marked increase in deposition of amyloid- $\beta$ protein in all layers of the cerebellum of fetus of the high dose group (Fig.18).

5) Mallory's trichrome stain: showed marked increase in deposition of collagen fibres in fetal cerebellar layers of the high dose group especially in the granular layers (Fig.19).

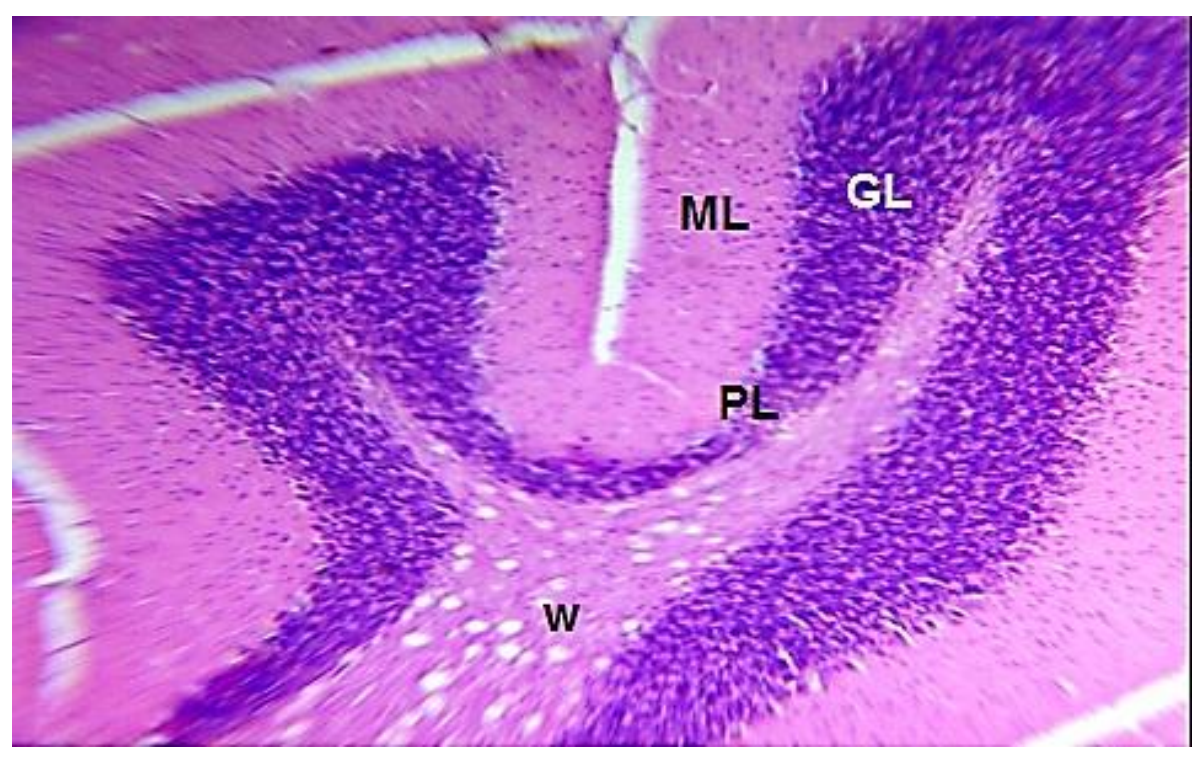

Fig.1: a photomicrograph of a paraffin section of the fetal cerebellar cortex of the control group (group I) showing the three layers of the cerebellar cortex from outside to inside; the outer molecular layer (ML), illdistinct purkinje cell layer (PL), the inner granule cell layer $(\mathbf{G L})$. And the core of white matter $(\mathbf{W})$.

$(\mathbf{H} \& \mathbf{E} \mathbf{x 1 0 0})$ 


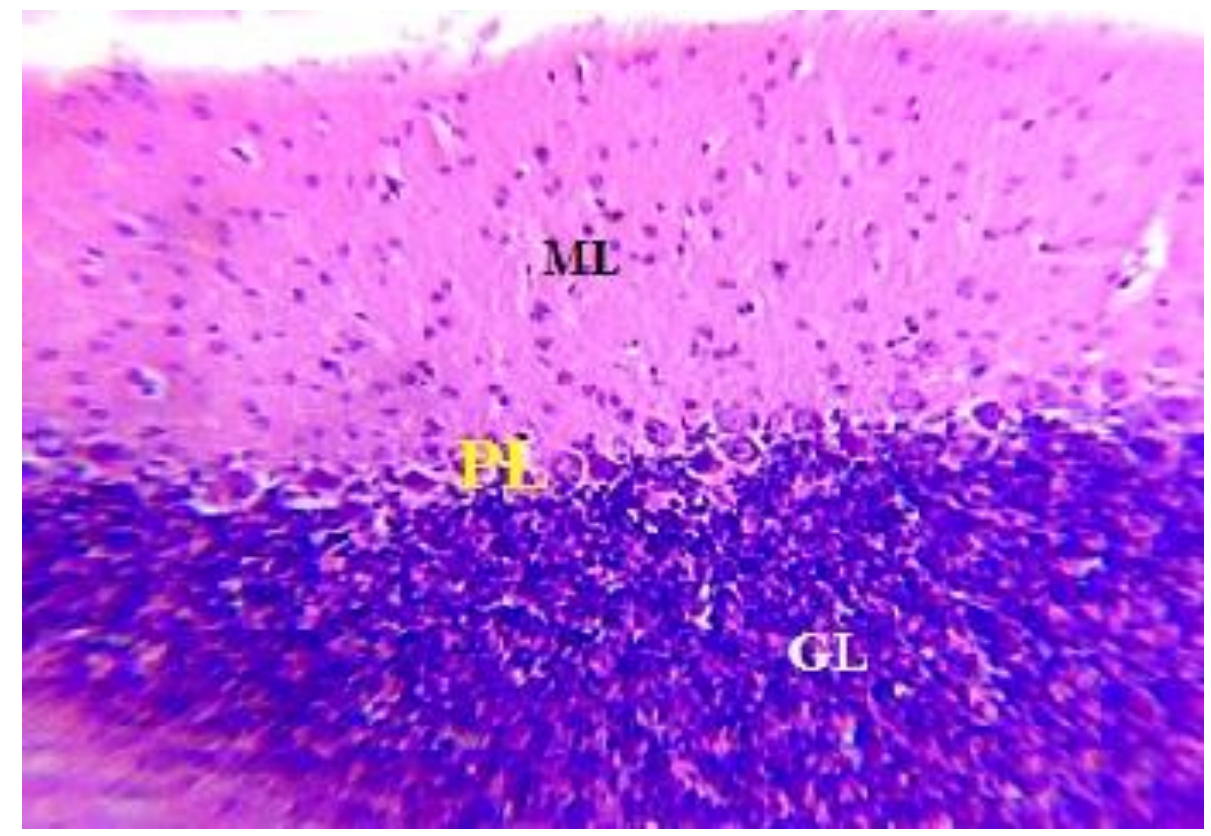

Fig.2: a photomicrograph of a paraffin section of the fetal cerebellar cortex of the control group (group I) showing the three layers of the cerebellar cortex from outside to inside; the outer molecular layer (ML), Purkinje cell layer $(\mathbf{P L})$ and the inner granule cell layer $(\mathbf{G L})$.

(H\&E x200)

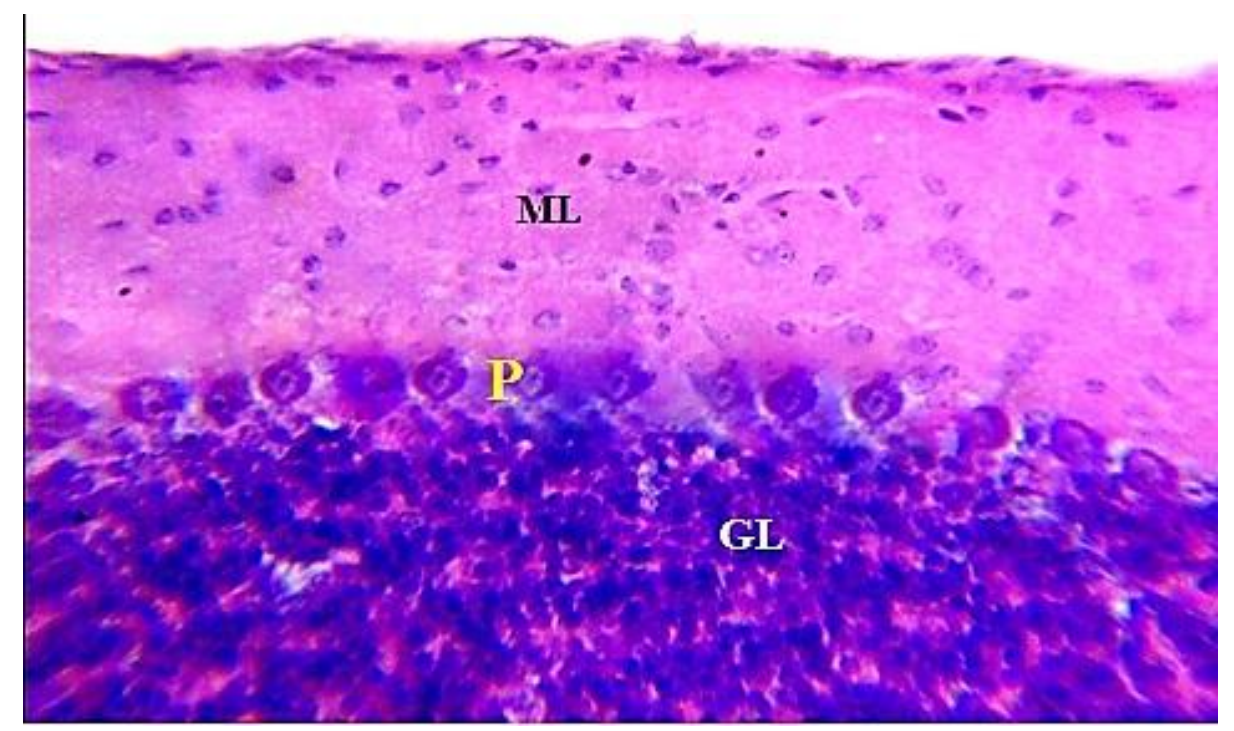

Fig. 3: a photomicrograph of a paraffin section of the fetal cerebellar cortex of the control group (group I) showing the classical pyriform shape of Purkinje cells $(\mathbf{P})$ with its strongly stained cytoplasm and normal appearance of the other three cortical layers; molecular layer (ML), granular layer (GL) with its darklystained neurons.

$(\mathbf{H} \& \mathbf{E} \times 400)$ 


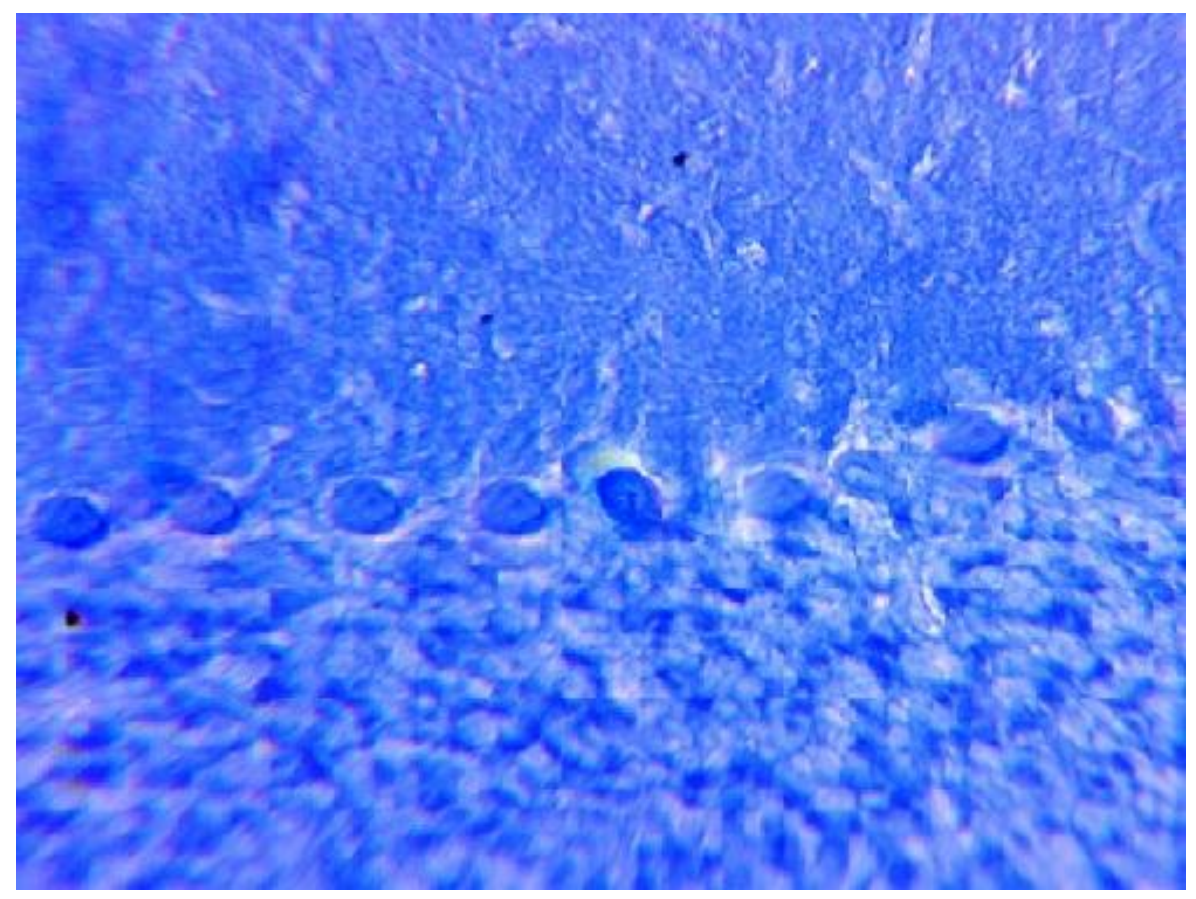

Fig. 4: a photomicrograph of a paraffin section of the fetal cerebellar cortex of the control group (group I) showing dense to moderate stain affinity of total protein (blue colour) in the Purkinje cells and granular layer cells with less stained molecular layer.

(Mercuric bromophenol blue $\mathbf{x 4 0 0 )}$

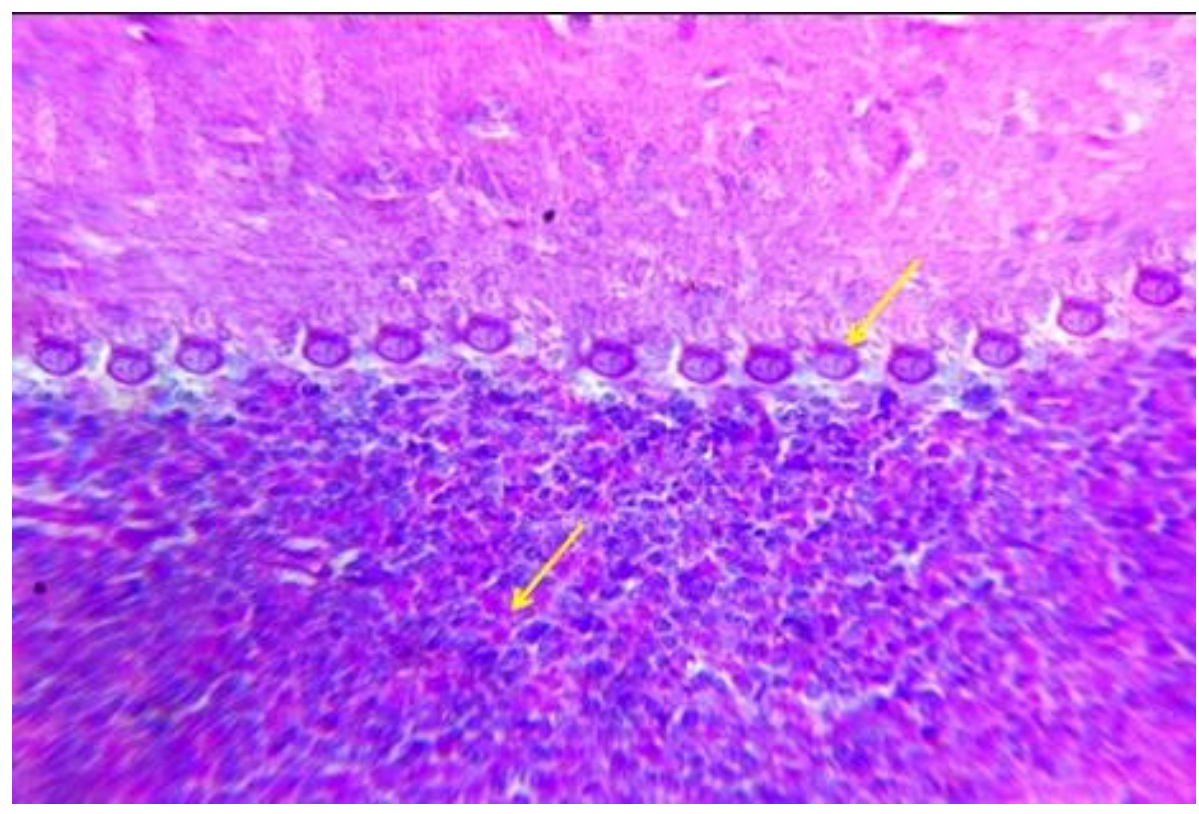

Fig. 5: a photomicrograph of a paraffin section of the fetal cerebellar cortex of the control group (group I) showing normal distribution of PAS +ve materials in all the cortical layers with dense staining affinity in Purkinje cells and granular layer cells (yellow arrows).

(PAS reaction $\mathrm{x} 400)$ 


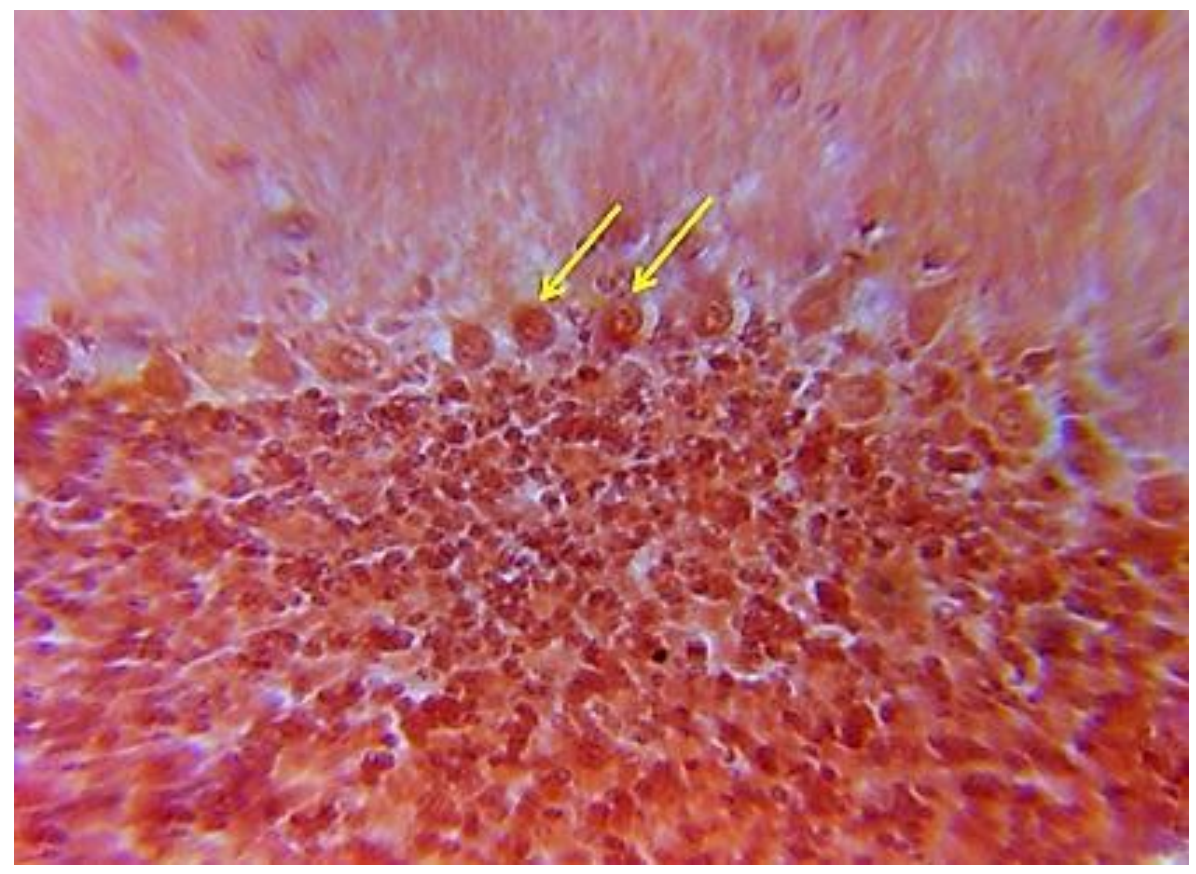

Fig.6: a photomicrograph of a paraffin section of the fetal cerebellar cortex of the control group (group I) showing slight deposition of amyloid $\beta$ in the nuclei of Purkinje cells (yellow arrows) with negative Congo red reaction in the remaining layers of the cerebellar cortex.

(Congo red x400)

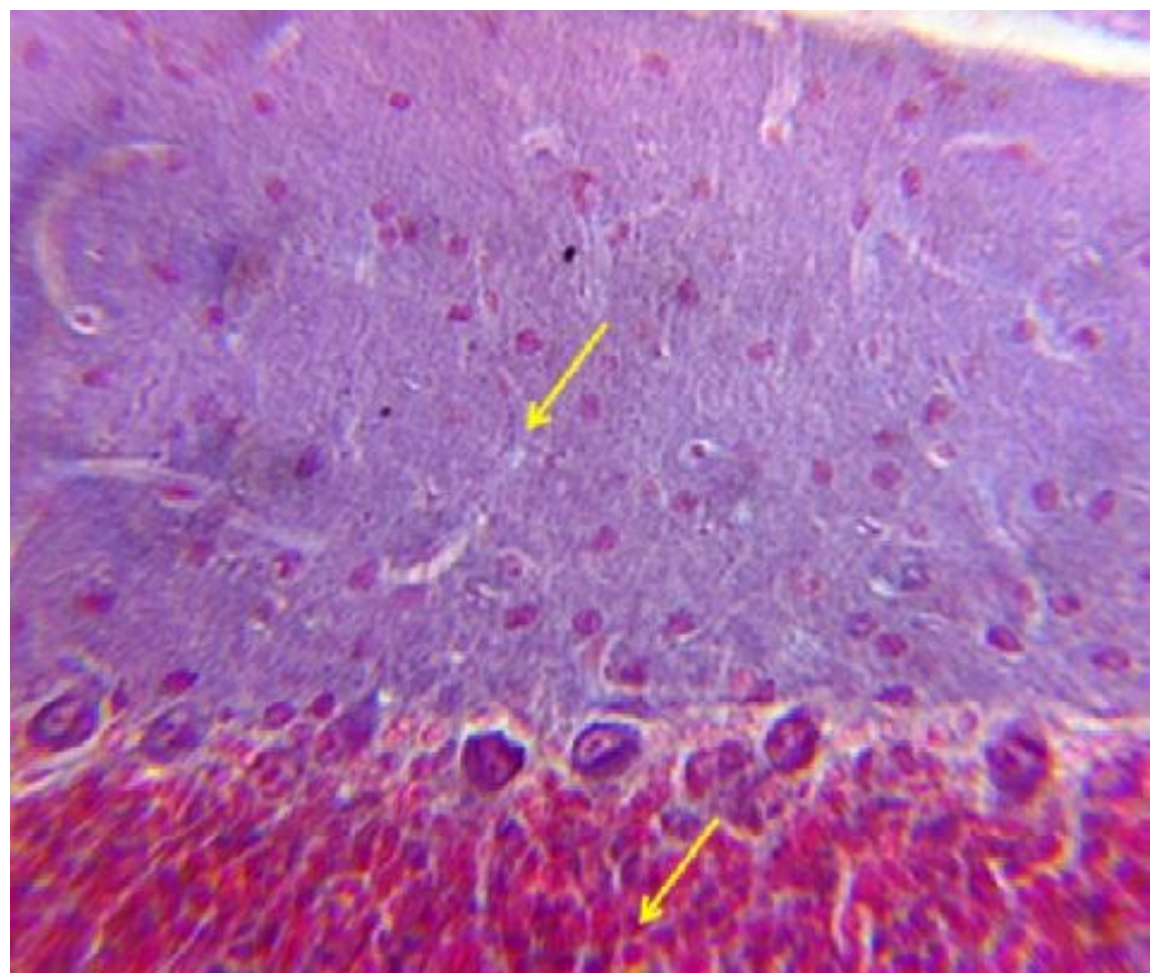

Fig.7: a photomicrograph of a paraffin section of the fetal cerebellar cortex of the control group (group I) showing ill distinct thin bundles of collagen fibers (yellow arrows) in the cerebellar cortical layers.

( Mallory's trichrome stain $\mathbf{x 4 0 0 )}$ 


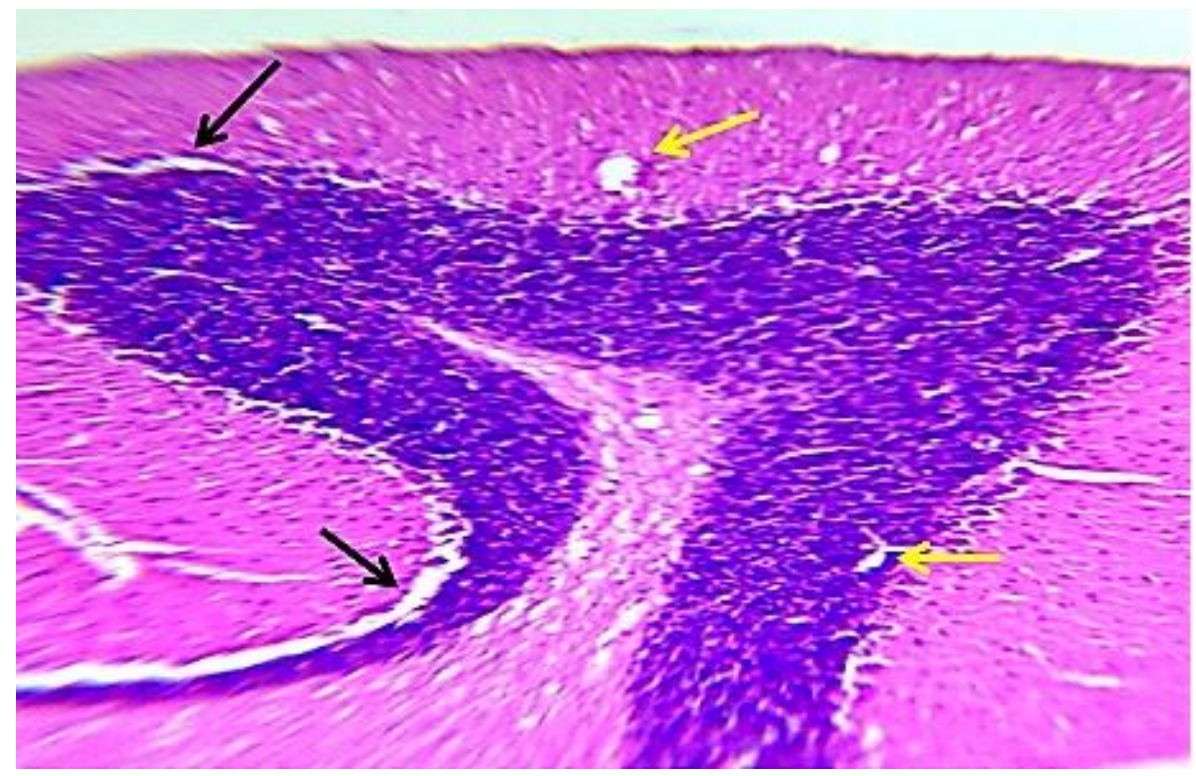

Fig.8: a photomicrograph of a paraffin section of the fetal cerebellar cortex of the therapeutic dose (group II) showing the three layers of the cerebellar cortex; microvacuolation in the neuropia of the outer molecular layer and the granular layers (yellow arrows), partial separation of the Purkinje cell layer from the inner granule cell layer (Black arrows).

(H\&E x100)

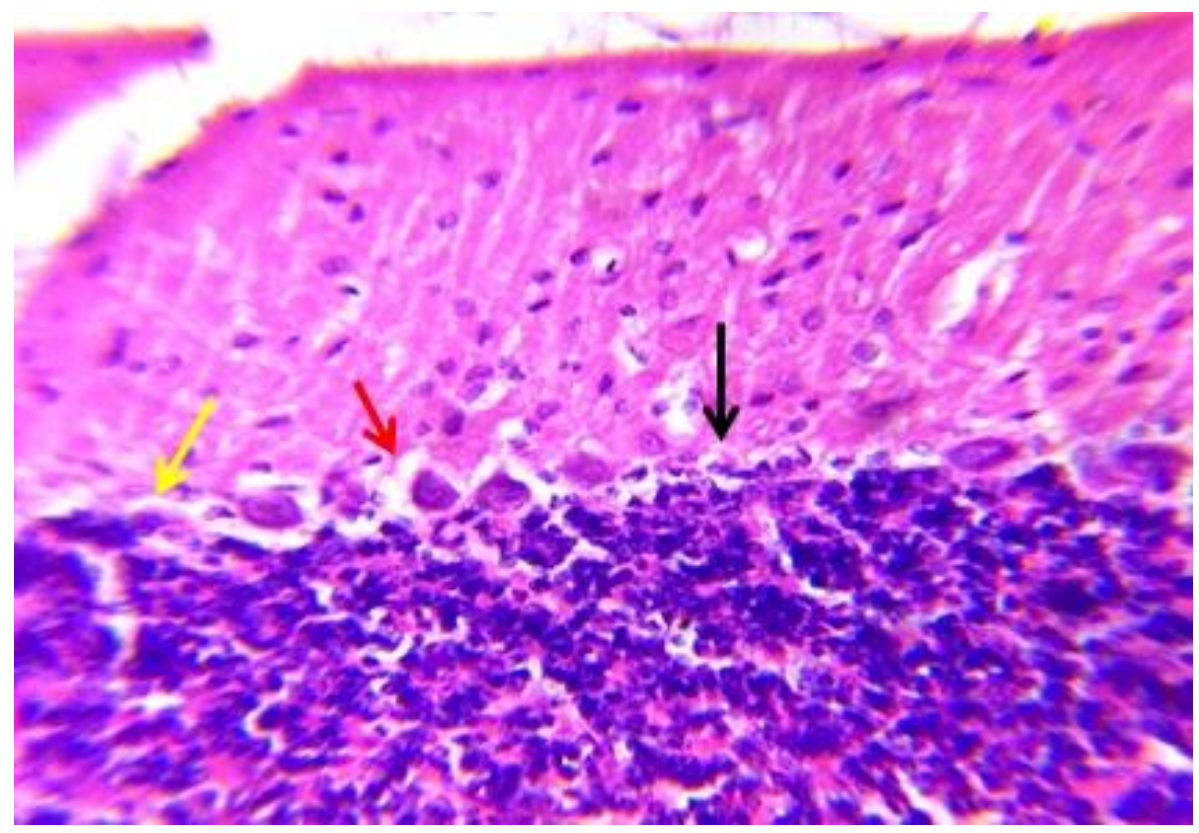

Fig.9: a photomicrograph of a paraffin section of the fetal cerebellar cortex of the therapeutic dose (group II) showing degenerative changes in the Pukinje cell layer in the form of partial loss of the Purkinje cells (black arrow), shrinkage of some Purkinje cells (red arrow), pericellular vacuolation around some Purkinje cells (yellow arrow).

$(\mathbf{H} \& \mathbf{E} \times 400)$ 


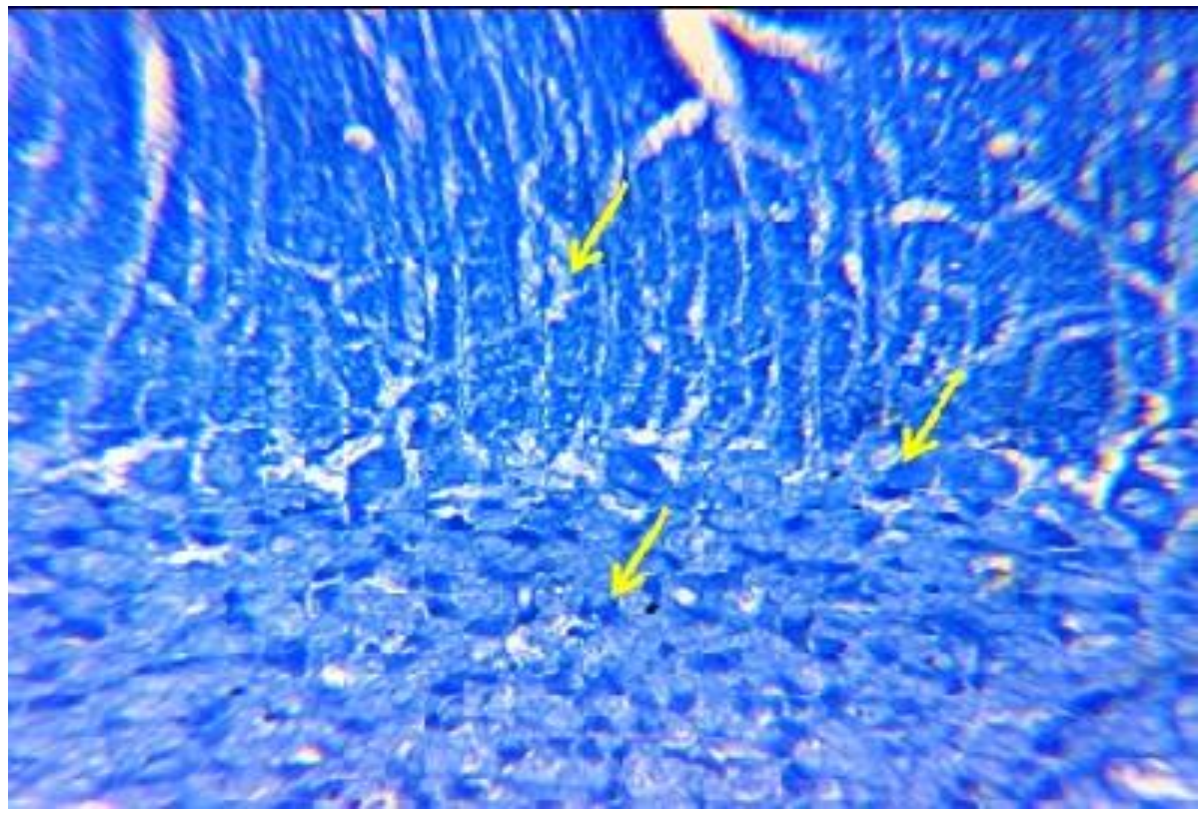

Fig.10: a photomicrograph of a paraffin section of the fetal cerebellar cortex of the therapeutic dose (group II) showing mild reduction in protein content in the different layers of cerebellum (yellow arrows).

(Mercuric bromophenol blue $\mathbf{x 4 0 0 )}$

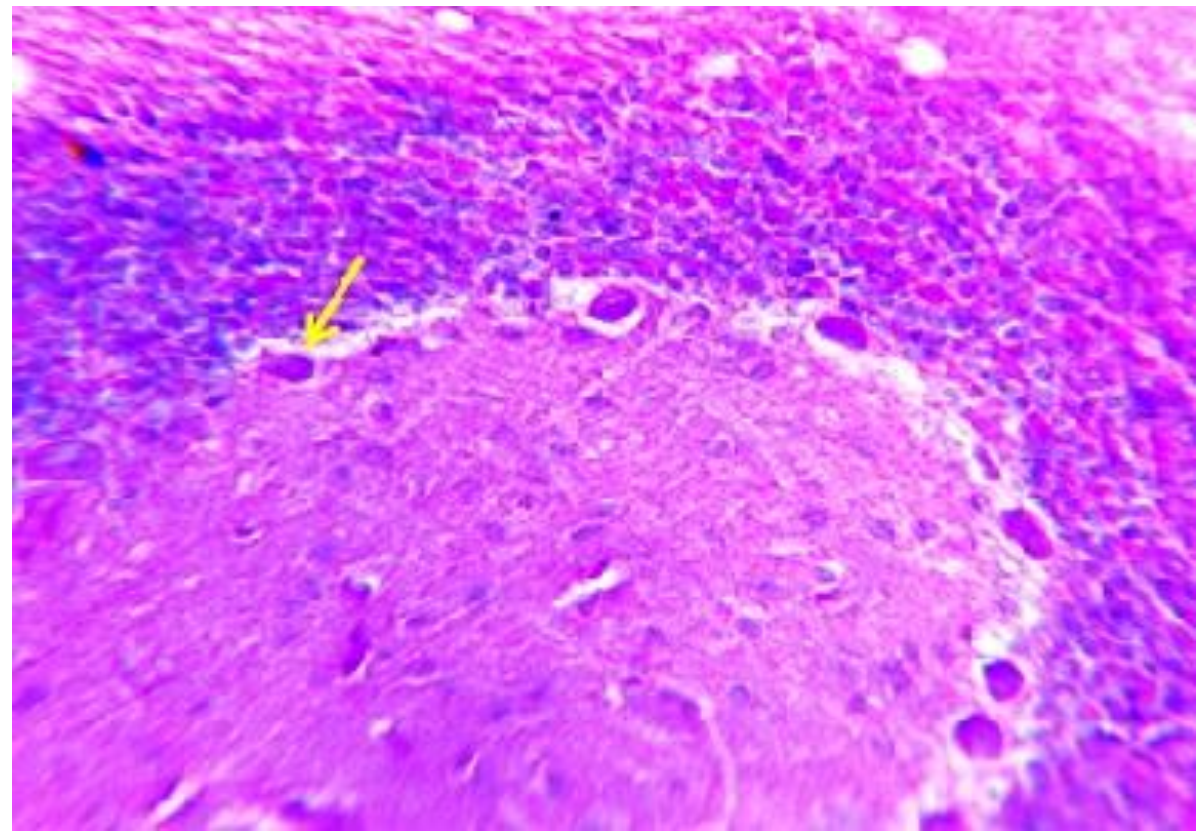

Fig.11: a photomicrograph of a paraffin section of the fetal cerebellar cortex of the therapeutic dose (group II) showing mild decrease in the PAS +ve materials especially in the shrinked Purkinje cells ( yellow arrow).

(PAS reaction $\mathrm{x} 400)$ 


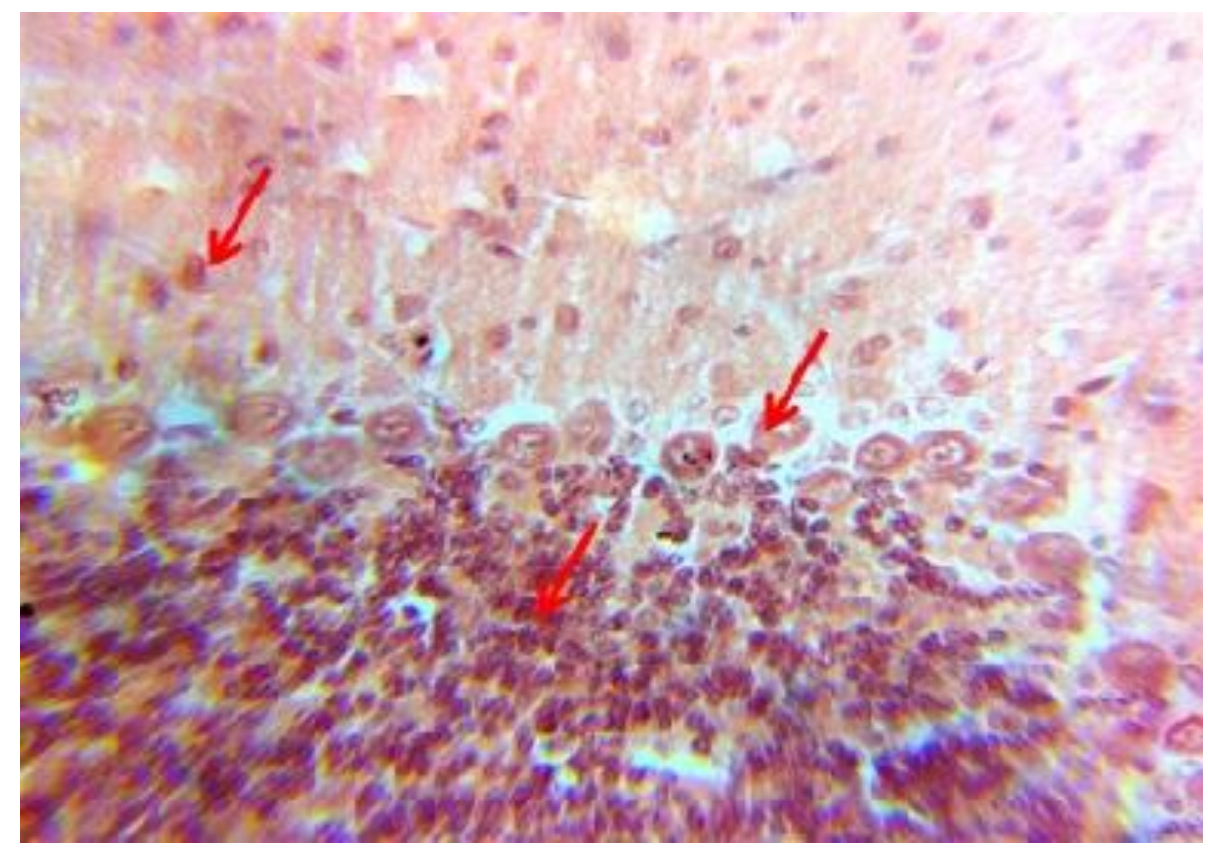

Fig.12: a photomicrograph of a paraffin section of the fetal cerebellar cortex of the therapeutic dose (group II) showing mild increase in deposition of amyloid- $\beta$ plaques in all layers of the cerebellum ( red arrows).

(Congo red $x 400)$

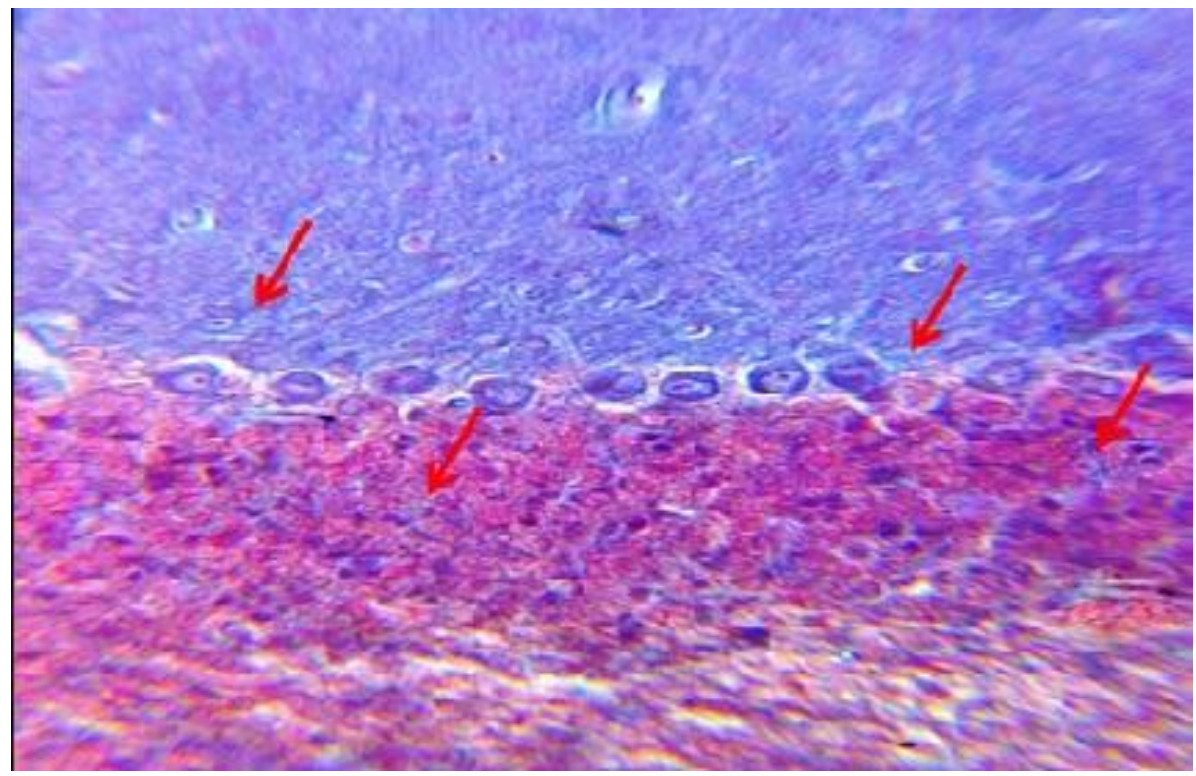

Fig.13: a photomicrograph of a paraffin section of the fetal cerebellar cortex of the therapeutic dose (group II) showing increased deposition of blue collagen fibres deposition especially in the granular layers (red arrows). 


\section{Nadia G. Zaki and Magdy H. Abouel-Magd}

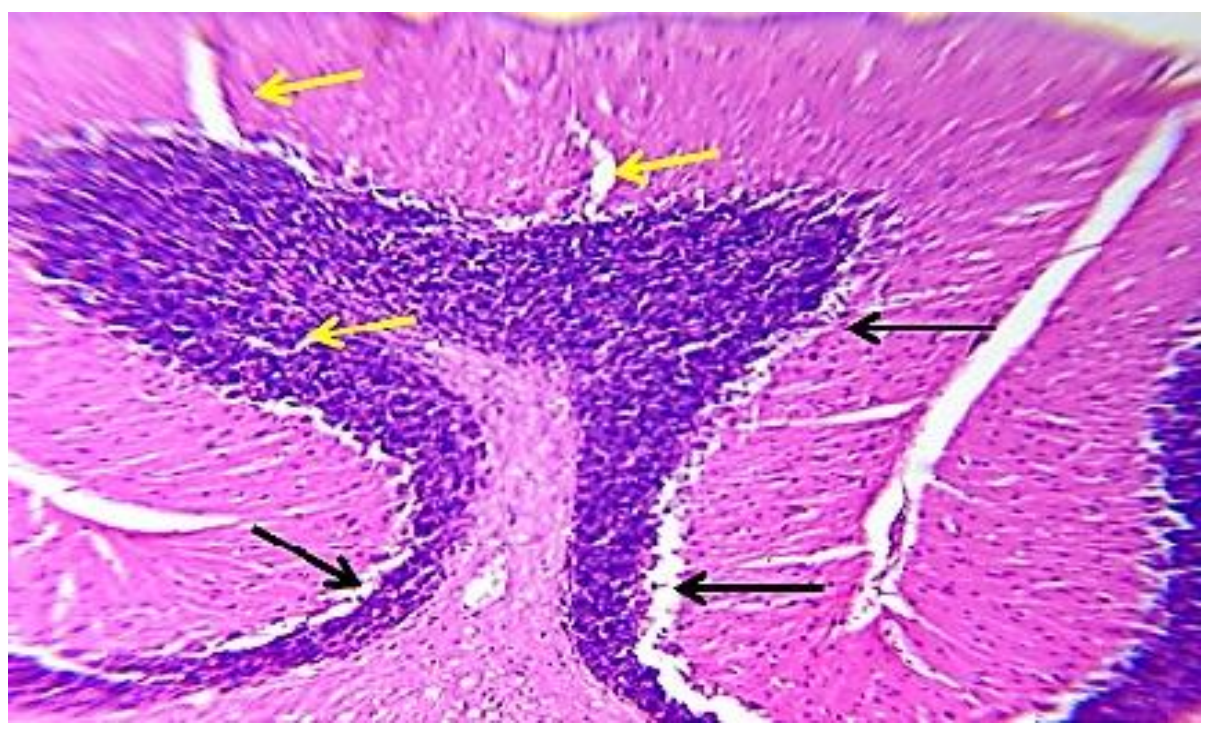

Fig.14: a photomicrograph of a paraffin section of the fetal cerebellar cortex of the toxic dose (group III) showing the three layers of the cerebellar cortex; macrovacuolation and separation in the neuropia of the outer molecular layer and the granular layers (yellow arrows), marked separation of the Purkinje cell layer from the inner granule cell layer (black arrows).

(H\&E x100)

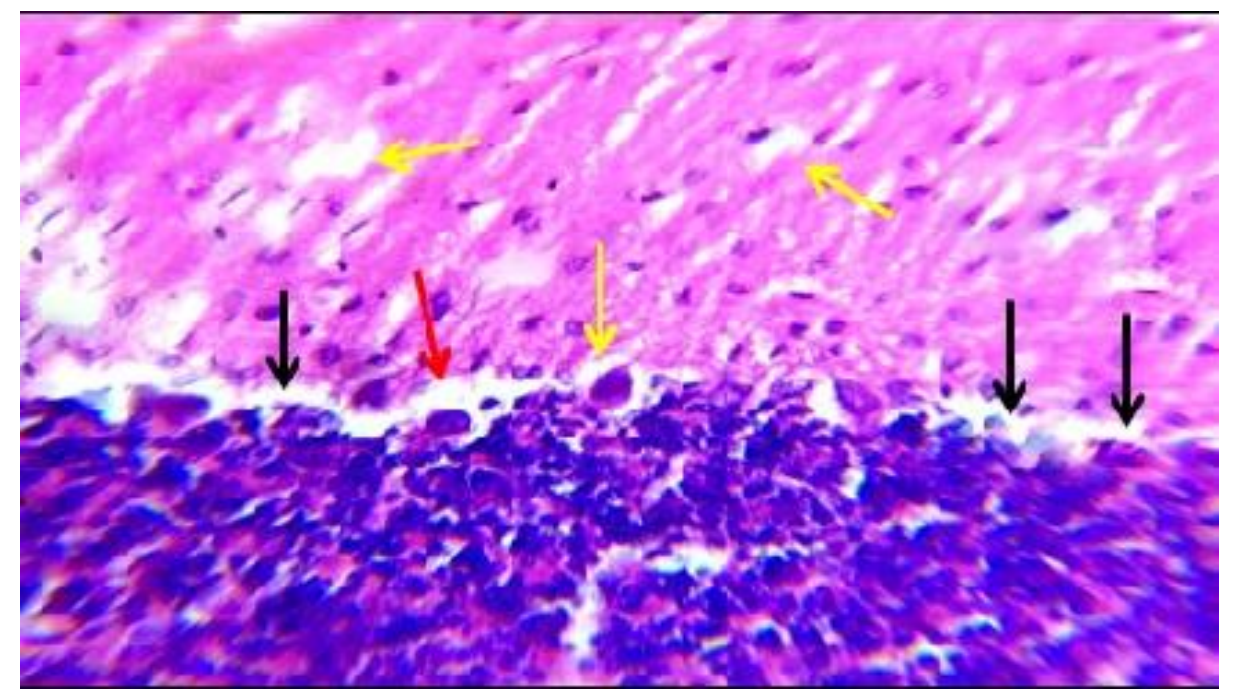

Fig.15: a photomicrograph of a paraffin section of the fetal cerebellar cortex of the toxic dose (group III) showing marked vacuolation in the neuropia of the molecular layer (yellow arrows), marked degenerative changes in the disrupted Pukinje cell layer in the form of marked empty spaces due to loss of the Purkinje cells (black arrows), marked shrinkage of most of the darkly stained Purkinje cells, marked pericellular vacuolation around most of Purkinje cells (red arrow).

(H\&E x400) 


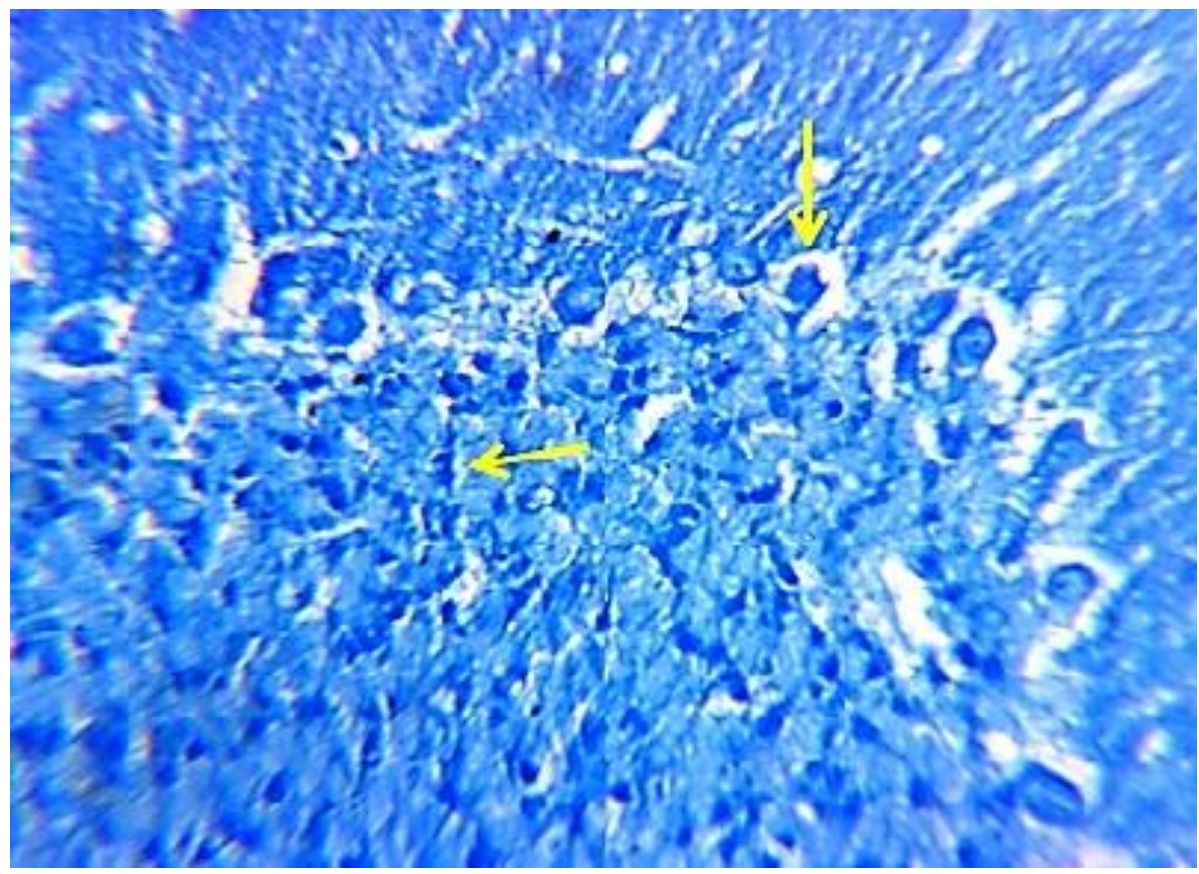

Fig.16: a photomicrograph of a paraffin section of the fetal cerebellar cortex of the toxic dose group (group III) showing marked reduction in protein content in the different layers of cerebellum (yellow arrows).

(Mercuric bromophenol blue $\mathrm{x} 400$ )

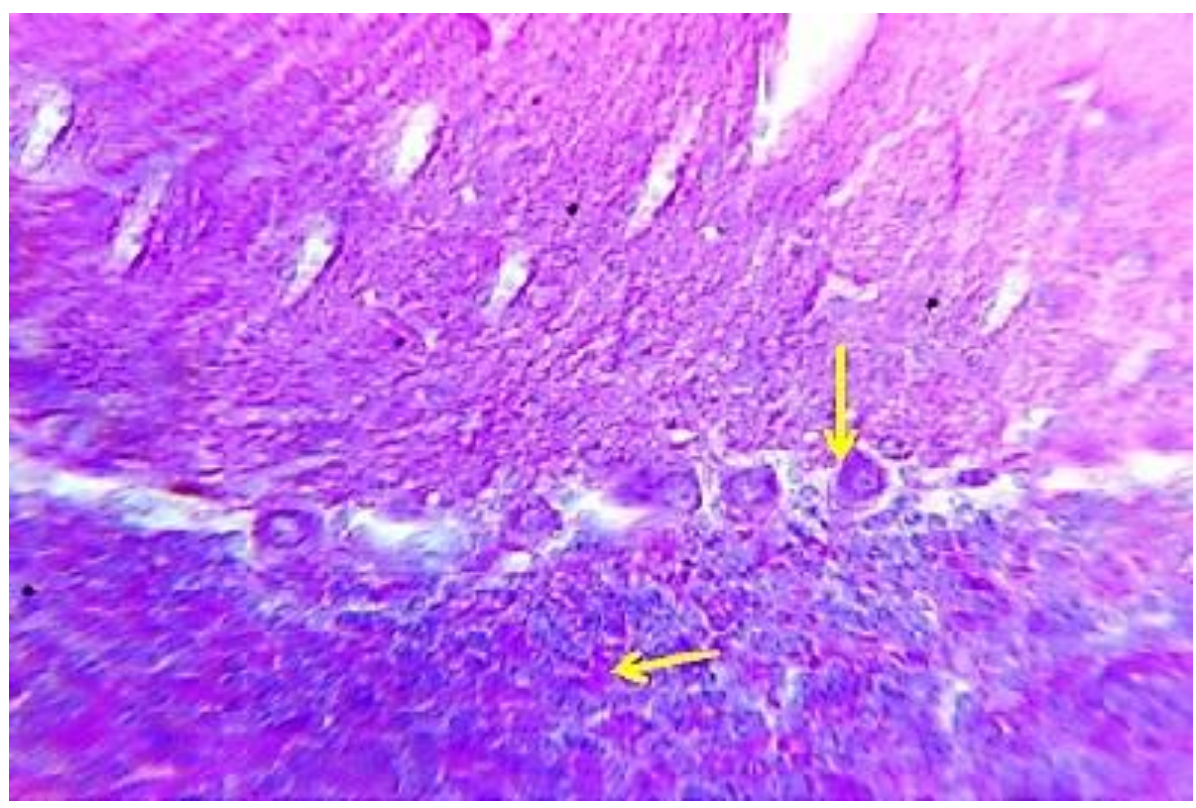

Fig.17: a photomicrograph of a paraffin section of the fetal cerebellar cortex of the toxic dose group (group III) showing Marked decrease in the PAS + ve materials in the destructed Purkinje cells and the granular layer (yellow arrows ).

(PAS reaction $\mathrm{x} 400)$ 
Nadia G. Zaki and Magdy H. Abouel-Magd

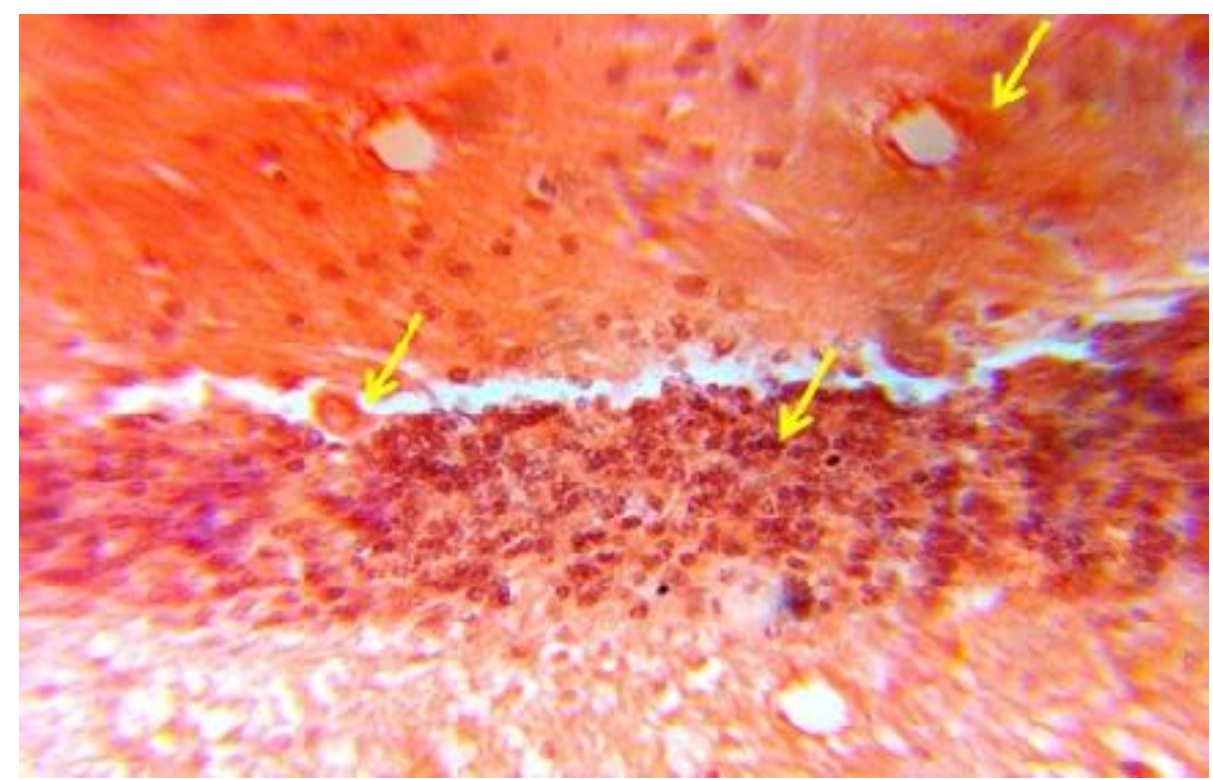

Fig.18: a photomicrograph of a paraffin section of the fetal cerebellar cortex of the toxic dose group (group III) showing marked increase in deposition of amyloid- $\beta$ plaques in all layers of the cerebellum (yellow arrows).

(Congo red x400)

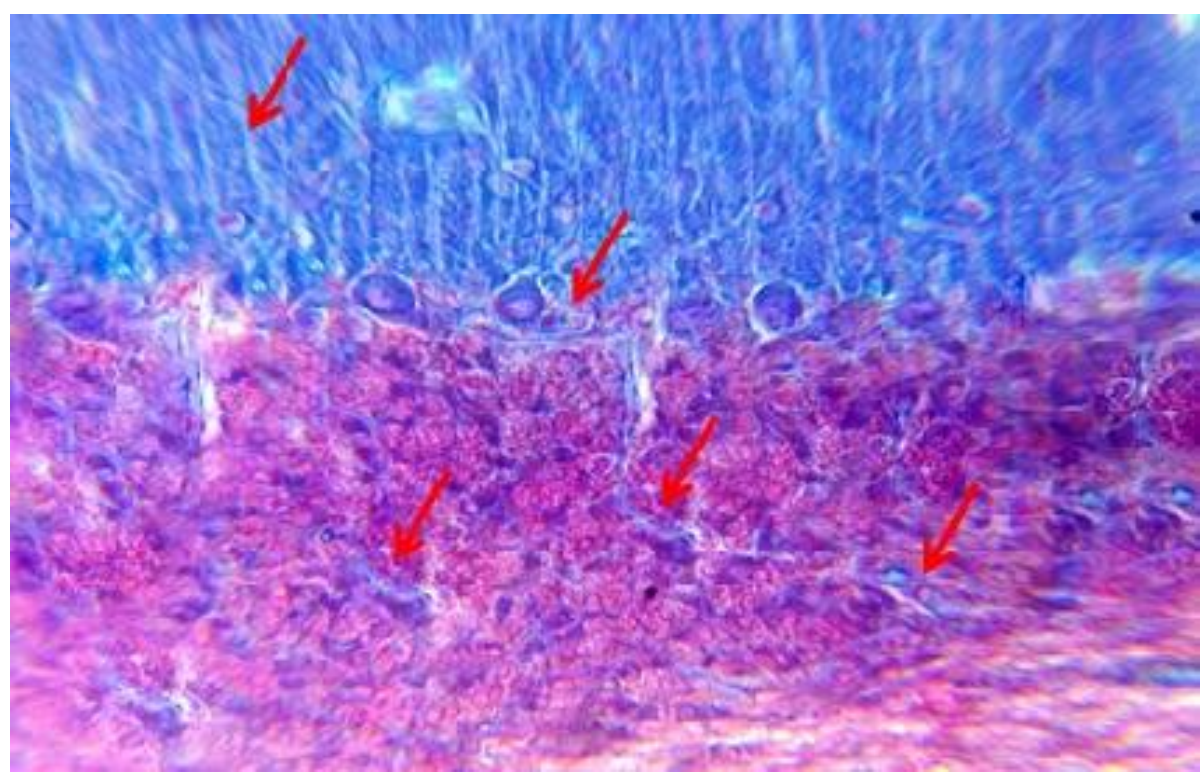

Fig.19: a photomicrograph of a paraffin section of the fetal cerebellar cortex of the toxic dose group (group III) showing marked increase in deposition of blue collagen fibres in all cerebellar layers especially in the granular layers (red arrows).

( Mallory's trichrome stain $\mathbf{x 4 0 0 )}$ 


\section{DISCUSSION}

Anxiety is a kind of emotional reaction in the form of unpleasant state when the people are facing challengs. Anxiety disorders are the most common mental disorders facing humans ${ }^{(11)}$.

Buspirone hydrochloride 8-[4-(4-pyrimidin2-ylpiperazin-1-yl)butyl]-8-azaspiro[4.5]decane-

7,9 dione;hydrochloride, is an anxiolytic drug that does not interact with benzodiazepine receptors and does not appear toact primarily by modulation of GABA\{The GABA receptors are a class of receptors that respond to the neuro-transmitter gamma-amino butyric acid\} ${ }^{(12)}$. Buspirone has high affinity for the 5- $\mathrm{HT}_{1 \mathrm{~A}}$ subtype of serotonin receptors, at which it acts as a partial agonist ${ }^{(13)}$. Buspirone also has relatively high affinity for dopamine receptors and has been shown to act as an antagonist at dopamine autoreceptors, resulting in an increase in brain dopamine turnover ${ }^{(14 \& 15)}$.

The actions of buspirone on dopamine autoreceptors and on serotonin $5-\mathrm{HT}_{1 \mathrm{~A}}$ receptors have been suggested to be possible mechanisms in its anxiolytic actions ${ }^{(16)}$.Buspirone, is a potent anxiolytic compound in animal models, it displays reversibility of synaptic activation of pyramidal cells in the hippocampus ${ }^{(17)}$.

It showed that buspirone binds selectively to presynaptic (dorsal raphe) and postsynaptic (hippocampus, cortex) ${ }^{(18)}$.The focus of the majority of animal studies has mainly been on effects of the buspirone on the brain tissue because of its target mode of action. The cerebellum was selected for this work because it is one of the most important regions of the brain with respect to the development ${ }^{(19)}$.

As regarding the current experiment, exposure of pregnant rats to buspirone hydrochloride in a doses of $0.27 \mathrm{mg} / 100 \mathrm{~g}$. and $0.41 \mathrm{mg} / 100 \mathrm{~g}$. body weight/day respectively for 15 days from the $6^{\text {th }}$ day to the $20^{\text {th }}$ day of gestation showed some dystrophic changes in the Purkinje cells layer represented by decreased number, degenerated and accumulated granular layer cells with edematous spaces. Increased pericellular spaces were also noted between the granular and Purkinje cells layers.As regarding the current findings, epithelial pial surface detachment and degeneration of Purkinje cells come in consonance with those reported earlier ${ }^{(20)}$. Increased collagen fibres deposition was noticed in the different cortical cerebellar layers of the exposed group especially in their white matter layer which comes in coincidence with results reported by Sagarduy et al.$^{(21)}$.

Khana et al. ${ }^{(22)}$ declared that decreased collagenolytic enzymes synthesis by the impaired cells could be contributed to the accumulation of collagen fibres. The disturbed histochemical pattern of polysaccharides, total proteins and amyloid $\beta$ protein reflected the hazardous effects of buspirone in the biochemical and histochemical aspects which preceded the pathological signs. Histochemical observations showed a mild decrease in the PAS +ve materials in the low and high dose treated groups, such decrease could be attributed to glucose uptake ${ }^{(23)}$.

As regarding the present experiment, the detectable decrease in both total protein and amyloid-B was also noticed by Mello et $\boldsymbol{a l l}^{(24)}$ and Bari et al. $\left.{ }^{(25)}\right)$. Such decrease may be due to the the histpathoogical changes observedin the different areas of brain which may be due to neurotoxic effect of buspirone.

\section{CONCLUSION}

Administration of buspirone hydrochloride (Buspar) for long duration resulted in some sorts of neurotoxic structural and histochemical changes as evident by deformity of the fetal cerebellar layers, decreased total proteins and degeneration of Purkinje cells of the fetal cerebellum tissue. 


\section{REFERENCES}

1- Butkevich IP, MikhailenkoVA, Vershinina EA, Semenov PO and Otellin VA (2011): Stress on measures of the pain response in effects of prenatal exposure to buspirone and inflammation and depression-like behavior in adult rats. Neurosci. Beha. Phys., 41:211-216.

2- Eskow KL, Gupta V and Alam S (2007): The partial $5-\mathrm{HT}_{1 \mathrm{~A}}$ agonist buspirone reduces the expression and development of 1-DOPA-induced dys kinesia in rats and improves 1-DOPA efficacy. Pharma. Bioch. Beha., 87: 306-314.

3- Fernandez G R, Reyes L, Martinez M and Munoz FL(2005): Influence of inflammatory no ciception on the anxiolytic-like effect of diaze-pam and buspirone in rats. J. Psycho. Pharma., 180: 399-407

4- Butkevich IP, Mikhailenko VA, Vershinina EA, Otellin VA and Aloisi AM ( $\left.\begin{array}{llll}2 & 0 & 1 & 1\end{array}\right)$ : Buspirone before prenatal stress protects against adverse effects of stress on emotional and inflammatory pain-related behaviors in infant rats: Age and sex differences. J. Brain Res., 9: 76-84.

5-Paget GE and Barnes JM (1964): Interspecies dosage conversion scheme in evaluation of results and quantitative application in different species. In: Evaluation of Drug Activities. Laurence D R and Bacharach A L (Eds.).Academic Press, London and USA., pp: 160-162.

6-Bancroft $J$ and Gamble $M$ (2002): Theory and Practice of Histology Techniques. $5^{\text {th }}$ ed. Churchil Livingstone, London. pp: 150-152.

7-Mazia D, Brewer PA and Alfert M (1953): The cytochemical staining and measurement of protein with mercuric bromophenol blue. Biol. Bull., 104(1): 57-67.

8-Carleton HM, Drury RAB and Wallington EA (1980): Carleton's Histological Technique. $4^{\text {th }}$ ed., Oxford Univ. Press, New York, USA. p. 520.

9-Valle $S$ (1986): Special stains in microwave oven. J. Histotechnol., 9(4): 237-239.

10-Pearse AG (1985): Histochemistry, Theoretical and Applied. Analytical Technology. $4^{\text {th }}$ ed., Churchill Livingstone, London. p. 594.

11-Baldwin DS, Anderson IM, Nutt DJ, Allgulander C, Bandelow B, den Boer JA and Malizia A (2014): Evidence-based pharmacological treatment of anxiety disorders, posttraumatic stress disorder and obsessivecompulsive disorder: a revision of the 2005 guidelines from the British Association for Psychopharmacology. J. Psychopharma., 28(5): 403-439.

12-Plummer F, Manea L, Trepel D and McMillan D (2016): Screening for anxiety disorders with the GAD-7 and GAD-2: systematic review and diagnostic metaanalysis. Gene. Hosp. Psychi., 39:24-31.

13-Youssef RM, Khamis EF, Gazy AA, Mahgoub H, El-Sayed MA (2006): Assay of buspirone hydrochloride in tablets using kinetic spectrophotometry.J. Chin. Pharm., 58:85-94.
14-Le Foll B, Payer D, Di Ciano1 P, Guranda1 M and Nakajima S (2016): Occupancy of dopamine D3 and D2 receptors by buspirone: A [11C]-(+)-PHNO PET study in humans. Inter. J. Neuropsycho., 41(2):529-537.

15-Haleem DJ, Ikram $H$ and Abdul Haleem M (2014): Inhibition of apomorphine-induced conditioned place preference in rats co-injected with buspirone: Relationship with serotonin and dopamine in the striatum. J.Brain Res., 15(1) :73-82.

16- Bshara H, Osman R, Mansour S and El-Shamy AA (2014): Chitosan and cyclodextrin in intranasal microemulsion for improved brain buspirone hydrochloride pharmacokinetics in rats. Carb. Poly., 99: 297-305.

17- Freitas RL, Santos IM, Souza GF and Tome AR (2010): Oxidative stress in rat hippocampus caused by pilocarpine-induced seizures is reversed by buspirone. Brain Res. Bull., 81: 505-509.

18-Jahanshahi A, Lim LW, Steinbusch HW and Vandewalle VV (2010): Buspirone-induced changes in the serotonergic and non-serotonergic cells in the dorsal raphe nucleus of rats. Neuro- science Letters. 473: 136140.

19-Kim SW, Fowler JS, Skolnick P, Muench $L$ and Kang Y, (2014): Therapeutic doses of buspirone block D3 receptors in the living primate brain. Inter. J. Neuropsycho., 17: 1257-1267.

20-Moron JA, Abul-Husn NS, Rozenfeld R, Dolios G, Wang $R$ and Devi LA (2007): Morphine administration alters the profile of hip- pocampal postsynaptic density-associated proteins a proteomics study focusing on endocytic proteins. Molec. Cellu. Proteo., 6(1): 29-42.

21-Sagarduy A, Llorente J, Miguelez C, MoreraHerreras $M$ and Ruiz-Ortega L (2016): Buspirone requires the intact nigrostriatal pathway to reduce the activity of the subthalamic nucleus via $5-\mathrm{HT}_{1 \mathrm{~A}}$ receptors. Experimental Neurology., 277: 35-45.

22-Khana S, Patila K,Yeolea $P$ and Gaikwadb $R$ (2009):Brain targeting studies on buspirone hydrochloride after intranasal administration of mucoadhesive formulation in rats. J. Pharmacy and Pharmaco., 61: 669-675.

23-Kumar JR, Rajkumar R, Lee LC and Dawe GS (2016): Nucleus incertus contributes to an anxiogenic effect of buspirone in rats: Involvement of $5-\mathrm{HT}_{1 \mathrm{~A}}$ receptors. J. Neuropharm., 110: 1-14.

24-Mello NK, Fivel PA and Kohut SJ (2013): Effects of Chronic Buspirone Treatment on Nicotine and Concurrent Nicotine p Cocaine Self-Administration. Inter. J. Neuropsycho., 38: 1264-1275.

25-Bari NK, Fazil M, Hassan Q, Haider R, Gaba B, Narang JK and Baboota S (2015): Brain delivery of buspirone hydrochloride chitosan nanoparticles for the treatment of general anxiety disorder. Inter. J. Bio. Macromol., 81: 49-59. 